\title{
PENGARUH PENGGUNAAN AIR SUHU EKSTRIM SEBAGAI BAHAN PEMBENTUK BETON YANG DITAMBAHKAN ADMIXTURES TERHADAP KUAT TEKAN BETON
}

\author{
Teuku Budi Aulia ${ }^{1)}$, Zahra Amalia ${ }^{2)}$ \\ ${ }^{1,2)}$ Jurusan Teknik Sipil, Fakultas Teknik, Universitas Syiah Kuala \\ Jl. Tgk. Syeh Abdul Rauf No. 7, Darussalam Banda Aceh 23111 \\ email:aulia@unsyiah.ac.id ${ }^{1)}$,zahra.amalia@unsyiah.ac.id ${ }^{21}$
}

DOI: http://dx.doi.org/10.29103/tj.v10i2.318

(Received: June 2020 / Revised: August 2020 / Accepted: August 2020)

\begin{abstract}
Abstrak
Perubahan iklim sebagai pemicu pemanasan global merupakan fenomena yang sudah terjadi selama beberapa dasawarsa terakhir. Penggunaan beton sebagai material konstruksi terus meningkat, hampir 60\% infrastruktur ketekniksipilan di dunia dibangun menggunakan beton. Penelitian ini bertujuan untuk mengetahui pengaruh pengunaan air bersuhu ekstrim sebagai bahan campuran beton yang ditambahkan admixtures, yaitu accelerator (Sika Cim) dan retarder (Plastiment RTD-01) terhadap kuat tekan beton untuk menghasilkan beton dengan mutu optimal. Air yang digunakan adalah air panas $\left(100^{\circ} \mathrm{C}\right)$, air dingin $\left(10^{\circ} \mathrm{C}\right)$, dan air suhu normal $\left(23^{\circ} \mathrm{C}\right)$. Persentase accelerator dan retarder yang dipakai adalah $0 \% ; 0,25 \% ; 0,50 \%$ dan $0,75 \%$ dari berat semen dengan faktor air semen (FAS) 0,$35 ; 0,40$ dan 0,45. Benda uji silinder standar $15 / 30 \mathrm{~cm}$ berjumlah 135 buah dibuat berdasarkan variasi FAS dan persentase admixtures, masing-masing perlakuan 5 benda uji pada umur pengujian 28 hari. Hasil penelitian menunjukkan beton dengan campuran air suhu ekstrim yang ditambahkan accelerator dan retarder dapat mempengaruhi kuat tekan beton bila dibandingkan dengan beton tanpa menggunakan admixtures. Kuat tekan beton untuk campuran air dingin mengalami peningkatan tertinggi pada FAS 0,$35 ; 0,40$ dan 0,45 pada penambahan accelerator $0,25 \%$ sebesar $0,119 \% ; 1,226 \%$ dan $2,314 \%$ dibandingkan campuran air suhu normal tanpa accelerator; sedangkan untuk campuran air panas mengalami peningkatan kuat tekan tertinggi pada FAS 0,35; 0,40 dan 0,45 dengan penambahan retarder $0,25 \%$ sebesar $10,345 \% ; 16,076 \%$ dan $23,471 \%$ bila dibandingkan dengan campuran air suhu normal tanpa penambahan retarder. Analisis varian menunjukkan bahwa penggunaan air suhu ekstrim dengan penambahan admixture mempunyai pengaruh signifikan terhadap kuat tekan beton pada setiap persentase admixtures dengan nilai optimum dicapai pada persentase $0,25 \%$.
\end{abstract}

Kata kunci: Kuat tekan beton, air suhu ekstrim, admixtures, accelerator, retarder

\begin{abstract}
Climate change as a trigger for global warming is a phenomenon that has been occurring in recent decades. The use of concrete as a construction material has been increasing, almost $60 \%$ of the world's civil-engineering infrastructures are made of concrete. The aim of this study is to find out the effect of extreme water temperature as mixing water in concrete which is added by admixtures, i.e., accelerator (SikaCim) and retarder (Plastiment RTD-01) on concrete compressive strength and to obtain its optimum value. Water used was hot water $\left(100^{\circ} \mathrm{C}\right)$, cold water $\left(10^{\circ} \mathrm{C}\right)$, and normal temperature water $\left(23^{\circ} \mathrm{C}\right)$. Accelerator and retarder used were $0 \% ; 0.25 \% ; 0.50 \%$ and $0.75 \%$ by cement weight with w/c-ratio $0.35 ; 0.40$; and 0.45 . The specimens were a standard 15/30 cylinder totaling 135 specimens based on variation of w/c-ratio and
\end{abstract}

Pengaruh Penggunaan Air Suhu Ekstrim Sebagai Bahan Pembentuk Beton Yang Ditambahkan Admixtures Terhadap Kuat Tekan Beton - Teuku Budi Aulia, Zahra Amalia 
percentage of admixtures, each variation has 5 specimens and was tested at 28 days. The results showed that extreme water temperature in concrete using accelerator and retarder affected concrete compressive strength compared to normal concrete without admixtures. The highest increase of compressive strength using both cold water and hot water of w/c-ratio $0.35 ; 0.40$; and 0.45 were at $0.25 \%$ of admixtures. They were $0.119 \% ; 1.226 \%$ and $2.314 \%$ for cold water respectively compared to normal mixing water temperature without accelerator, while for hot water were $10.345 \% ; 16.076 \%$ and $23.471 \%$ respectively compared to normal mixing water temperature without retarder. Varian analysis showed that extreme temperature of concrete mixed water using admixtures has a significant effect of concrete compressive strength at each percentage admixtures with the optimum value reached at $0.25 \%$.

Keywords: concrete compressive strength, extreme water temperature, admixtures, accelerator, retarder

\section{Latar Belakang}

Kuantitas dan kualitas air dalam campuran beton memiliki dampak langsung pada kekuatan dan durabilitas beton. Pada campuran beton, air memiliki peran yang sangat penting dalam proses hidrasi semen untuk menghasilkan CalciumSilicate-Hydrate (C-S-H) yang diperlukan untuk membentuk kekuatan beton. Laju reaksi hidrasi tersebut sangat bergantung pada temperatur, baik temperatur material maupun temperatur lingkungannya. Kondisi cuaca yang tidak dapat dikendalikan menjadi salah satu permasalahan dalam proses pembuatan beton. (Assal dan Abou-Zeid, 2019) menyebutkan bahwa kondisi cuaca baik pada saat temperatur yang rendah maupun pada saat temperatur tinggi dapat mempengaruhi secara langsung perilaku, kinerja dan sifat-sifat beton saat pencampuran, transportasi, pengecoran dan perawatan. (Naganathan dan Mustapha, 2015) melalui penelitiannya menyimpulkan bahwa temperatur air campuran beton $20^{\circ} \mathrm{C}$ hingga $35^{\circ} \mathrm{C}$ dapat memberikan hasil yang optimal terhadap kualitas beton.

Air campuran dapat menjadi salah satu material yang dapat mengontrol temperatur beton. Oleh karena itu, pada saat kondisi cuaca yang panas dapat digunakan air campuran yang dingin, sebaliknya pada saat kondisi cuaca yang dingin dapat digunakan air campuran yang panas. Namun, pencampuran beton dengan menggunakan air dingin dan air panas tersebut dapat mempengaruhi waktu pengikatan beton. Hal tersebut dapat diatasi dengan penggunaan admixtures. Accelerator dan retarder adalah dua jenis admixtures yang umum digunakan untuk mengatasi dampak negatif sifat beton segar akibat temperatur air campuran yang ekstrim. Accelerator dan retarder dapat mengontrol waktu pengikatan beton sehingga memperbaiki workabilitasnya. Accelerator dapat menjadi alternatif untuk menghindari proses pengikatan dan pengerasan campuran yang lama, sebaliknya retarder dapat menjadi alternatif untuk menghindari proses pengikatan dan pengerasan campuran yang cepat.

Beberapa penelitian telah dilakukan terkait pengaruh temperatur lingkungan dan temperatur air campuran beton tanpa menggunakan admixtures (Madi dkk., 2017; Assal dan Abou-Zeid, 2019). Penelitian tersebut menunjukkan bahwa temperatur air pada campuran beton mempengaruhi kekuatan dan workabilitas beton. Namun, studi mengenai pengaruh admixtures yang digunakan dalam campuran beton menggunakan air campuran bertemperatur ekstrim masih perlu dipelajari lebih lanjut.

Pengaruh Penggunaan Air Suhu Ekstrim Sebagai Bahan Pembentuk Beton Yang Ditambahkan Admixtures Terhadap Kuat Tekan Beton - Teuku Budi Aulia, Zahra Amalia 
Studi ini bertujuan untuk mengetahui pengaruh dari penggunaan air dengan temperatur ekstrim terhadap kuat tekan beton akibat penambahan accelerator dan retarder dengan membandingkannya terhadap beton yang menggunakan air dengan temperatur normal tanpa penambahan accelerator dan retarder untuk memperoleh beton dengan mutu optimal.

\section{Metode Penelitian}

\subsection{Parameter pengujian}

Pada studi ini temperatur air campuran beton ekstrim didefinisikan dengan air yang memiliki temperatur $10^{\circ} \mathrm{C}$ dan $100^{\circ} \mathrm{C}$. Selanjutnya, temperatur air campuran beton $10^{\circ} \mathrm{C}$ dan $100^{\circ} \mathrm{C}$ disebut temperatur air campuran beton menggunakan air dingin dan air panas secara berurutan. Perbedaan temperatur air campuran beton merupakan parameter pengujian yang utama. Disamping itu, persentase admixtures dan penggunaan faktor air semen (FAS) divariasikan untuk dilihat pengaruhnya sehingga dapat diperoleh nilai FAS dan persentase admixture yang optimum. Tabel 1 menunjukkan jumlah benda uji dan variasi parameter pengujian. Pada studi ini, variasi persentase admixtures mengacu pada data teknis produk dari PT. Sika Indonesia yang mensyaratkan jumlah persentase maksimum admixtures adalah $1 \%$ dari berat semen, sehingga persentase admixtures yang diteliti adalah $0 \%, 0,25 \%, 0,50 \%$ dan $0,75 \%$ dari berat semen.

Admixtures yang digunakan dalam penelitian ini adalah accelerator dan retarder. Accelerator digunakan pada campuran beton mengunakan air dingin dan retarder digunakan pada campuran beton menggunakan air panas.

Tabel 1 Parameter pengujian

\begin{tabular}{|c|c|c|c|c|c|}
\hline \multirow{2}{*}{ Temperatur air } & \multirow{2}{*}{$\begin{array}{c}\text { Jenis } \\
\text { Admixtures }\end{array}$} & \multirow{2}{*}{$\begin{array}{c}\text { Persentase } \\
\text { admixtures } \\
\text { (dari berat } \\
\text { semen) }\end{array}$} & \multicolumn{3}{|c|}{$\begin{array}{c}\text { Jumlah benda uji untuk tiap } \\
\text { nilai FAS (buah) }\end{array}$} \\
\hline & & & 0,35 & $\mathbf{0 , 4 0}$ & 0,45 \\
\hline$\overline{10^{\circ} \mathrm{C}}$ & Accelerator & 0 & 5 & 5 & 5 \\
\hline \multirow[t]{3}{*}{ (Air dingin) } & & 0,25 & 5 & 5 & 5 \\
\hline & & 0,5 & 5 & 5 & 5 \\
\hline & & 0,75 & 5 & 5 & 5 \\
\hline $100^{\circ} \mathrm{C}$ & Retarder & 0 & 5 & 5 & 5 \\
\hline \multirow[t]{3}{*}{ (Air panas) } & & 0,25 & 5 & 5 & 5 \\
\hline & & 0,5 & 5 & 5 & 5 \\
\hline & & 0,75 & 5 & 5 & 5 \\
\hline Air temperatur normal & - & - & 5 & 5 & 5 \\
\hline Total benda uji & & & & & \\
\hline
\end{tabular}

\subsection{Benda Uji dan Material}

Pada studi eksperimental digunakan benda uji silinder dengan ukuran diameter $150 \mathrm{~mm}$ dan tinggi $300 \mathrm{~mm}$. Hal ini sesuai dengan standar ukuran benda uji untuk pengujian kuat tekan beton menurut (SNI 1974, 2011). Semen Portland digunakan untuk membuat beton dengan ukuran agregat maksimum 25,4 mm. Perencanaan campuran beton dihitung berdasarkan metode (ACI Committee 211, 2009) untuk beton normal dengan gradasi butiran agregat campuran berpedoman pada (SNI, 2013). Perencanaan

Pengaruh Penggunaan Air Suhu Ekstrim Sebagai Bahan Pembentuk Beton Yang Ditambahkan Admixtures Terhadap Kuat Tekan Beton - Teuku Budi Aulia, Zahra Amalia 
campuran beton didasarkan pada slump rencana yaitu diantara $75 \mathrm{~mm}$ hingga $100 \mathrm{~mm}$.

Sifat-sifat fisis material diuji dengan standar ASTM seperti berat jenis dan absorbsi (ASTM, 1997), berat volume (ASTM C127, 2004), analisa saringan (American Society for Testing and Materials, 2014) dan kandungan bahan organik (sifat kimia) pasir halus (ASTM International, 2004) sebelum dilakukan perhitungan perencanaan campuran beton. Proporsi campuran beton disajikan pada Tabel 2.

Tabel 2 Proporsi campuran beton

\begin{tabular}{ccccc}
\hline \multirow{2}{*}{ FAS } & \multicolumn{4}{c}{ Unit $\left(\mathbf{k g} / \mathbf{m}^{\mathbf{3}}\right)$} \\
\cline { 2 - 5 } & Air & Semen & Agregat Kasar & Pasir Halus \\
\hline 0,35 & 192,62 & 550,33 & 819,01 & 819,01 \\
0,40 & 192,62 & 481,54 & 853,40 & 853,40 \\
0,45 & 192,62 & 428,04 & 880,15 & 880,15 \\
\hline
\end{tabular}

Es digunakan untuk mendinginkan air campuran beton hingga diperoleh air dengan temperatur $10^{\circ} \mathrm{C}$. Selanjutnya untuk air campuran beton dengan temperatur $100^{\circ} \mathrm{C}$ diperoleh dengan memanaskan air menggunakan kompos gas elpiji. Nilai slump diukur menggunakan kerucut Abrams saat proses pengecoran. Benda uji dibuka dari cetakan setelah 24 jam dan dilakukan perawatan sesuai standar (ASTM, 2008). Perawatan benda uji dilakukan dengan cara merendam beton dalam air. Pengujian kuat tekan beton dilakukan setelah benda uji dirawat selama 28 hari.

Admixtures yang digunakan yaitu accelerator jenis Sikacim Accelerator, sedangkan untuk retarder digunakan jenis RTD-01 berbahan dasar Polyhydroxy Carbon Salts yang keduanya diperoleh dari PT. Sika Indonesia. Tabel 3 menunjukkan karakteristik dari admixtures yang dipakai.

Tabel 3 Karakteristik admixtures

\begin{tabular}{lccc}
\hline \multirow{2}{*}{ Admixtures } & \multicolumn{3}{c}{ Parameter karakteristik } \\
\cline { 2 - 4 } & Bentuk & Warna & Berat jenis \\
\hline Sikacim Accelerator & Cairan & Tidak berwarna & $1,28 \mathrm{~kg} / \mathrm{ltr}$ \\
RTD-01 & Cairan & Hitam pekat & $1,17-1,19 \mathrm{~kg} / \mathrm{ltr}$ \\
\hline
\end{tabular}

Sumber: (PT. Sika Indonesia, 2007)

\subsection{Pengujian Kuat Tekan Beton}

Nilai kuat tekan beton didapatkan melalui standar pengujian sesuai (ASTM, 2008). Kuat tekan masing-masing benda uji ditentukan oleh tegangan tekan tertinggi $\left(f_{c}^{\prime}\right)$ yang dicapai benda uji pada umur 28 hari. Menurut (Amri, 2005) kuat tekan beton dapat dihitung dengan menggunakan Persamaan (1):

$$
f_{c}^{\prime}=\frac{P}{A}
$$

di mana $f_{c}^{\prime}$ adalah kuat tekan silinder beton $\left(\mathrm{kg} / \mathrm{cm}^{2}\right), P$ dan $A$ adalah beban tekan maksimum/hancur $(\mathrm{kg})$ dan luas penampang benda uji $\left(\mathrm{cm}^{2}\right)$ secara berurutan.

Pengaruh Penggunaan Air Suhu Ekstrim Sebagai Bahan Pembentuk Beton Yang Ditambahkan Admixtures Terhadap Kuat Tekan Beton - Teuku Budi Aulia, Zahra Amalia 
Kekuatan tekan beton akan bertambah dengan naiknya umur beton. Kekuatan beton akan naik secara cepat sampai umur 28 hari, tetapi setelah itu kenaikannya akan kecil (Mulyono, 2003).

Saat pengujian kuat tekan beton, perpendekan benda uji diukur menggunakan tranduser yang dipasang pada frame gage seperti yang terlihat pada Gambar 1. Besarnya regangan yang terjadi menurut (Gere dan Timoshenko, 1997) dapat dihitung dengan menggunakan Persamaan (2):

$$
\varepsilon=\frac{\Delta L}{L}
$$

di mana $\varepsilon$ merupakan regangan, $\Delta L$ dan $L$ adalah besarnya perpendekan yang terjadi $(\mathrm{cm})$ dan panjang pengamatan mula-mula $(\mathrm{cm})$.

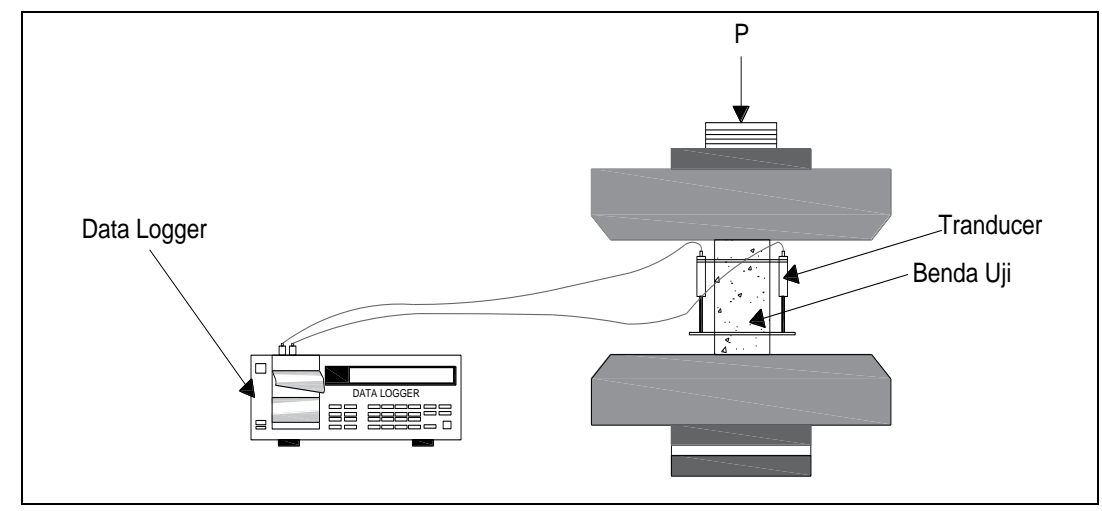

Gambar 1 Set-up pengujian kuat tekan beton

\section{Hasil dan Pembahasan}

Pengolahan data hasil penelitian dilakukan secara statistik. Koefisien ragam sampel (covarian) digunakan untuk mengetahui klasifikasi penyebaran data hasil pengujian. Pengaruh yang nyata dari perbedaan FAS dengan variasi persentase admixtures (accelerator dan retarder) terhadap kuat tekan beton dilakukan dengan analisa varian. Selanjutnya, analisis regresi digunakan untuk mengetahui bentuk hubungan FAS dengan variasi persentase admixtures (accelerator dan retarder) terhadap kuat tekan beton. Analisis varian untuk pengujian nyata regresi digunakan untuk mengetahui model regresi yang diperoleh.

\subsection{Waktu Pengikatan dan Workabilitas Beton}

Temperatur mortar beton normal tanpa penambahan admixtures adalah $28^{\circ} \mathrm{C}$. Pada campuran beton dengan air dingin dan air panas, temperatur mortar relatif sama untuk setiap FAS yaitu $22^{\circ} \mathrm{C}$ dan $45^{\circ} \mathrm{C}$ secara berurutan. Perubahan temperatur ini disebabkan karena air bertemperatur ekstrim telah bercampur dengan material lainnya yang bertemperatur berbeda dengan air pencampur. Perubahan temperatur mortar pada persentase admixtures yang berbeda untuk campuran beton dengan air dingin dan air panas, secara berurutan dapat dilihat pada Gambar 2 dan Gambar 3.

Gambar 4 dan Gambar 5 menunjukkan hubungan nilai slump terhadap waktu untuk FAS 0,45. Perbedaan nilai slump beton segar terhadap waktu dapat terlihat

Pengaruh Penggunaan Air Suhu Ekstrim Sebagai Bahan Pembentuk Beton Yang Ditambahkan Admixtures Terhadap Kuat Tekan Beton - Teuku Budi Aulia, Zahra Amalia 
antara campuran beton menggunakan air dingin dan air panas. Penurunan nilai slump pada menit awal cenderung lambat pada beton dengan campuran air dingin dengan tambahan accelerator. Perilaku yang sebaliknya terlihat pada campuran beton dengan air panas yang ditambahkan retarder, dimana terjadi penurunan secara cepat nilai slump di menit awal. Perilaku yang relatif sama terlihat pada FAS 0,40 dan FAS 0,35 yang disajikan pada Gambar 6 hingga Gambar 9. Hasil yang diperoleh pada studi ini sejalan dengan hasil pada penelitian oleh (Renjuraj dkk., 2016).

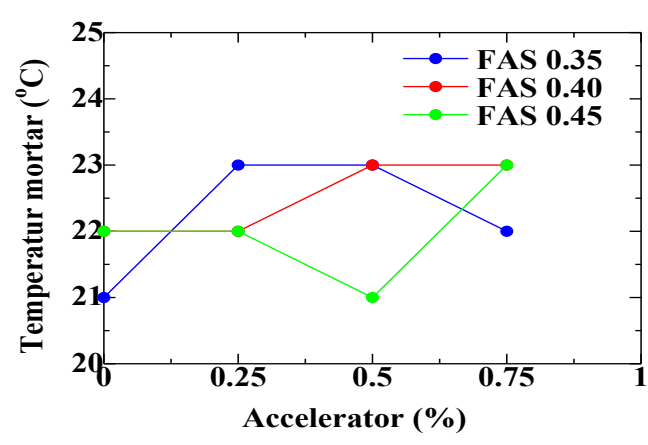

Gambar 2 Hubungan temperatur mortar dengan persentase accelerator campuran air dingin

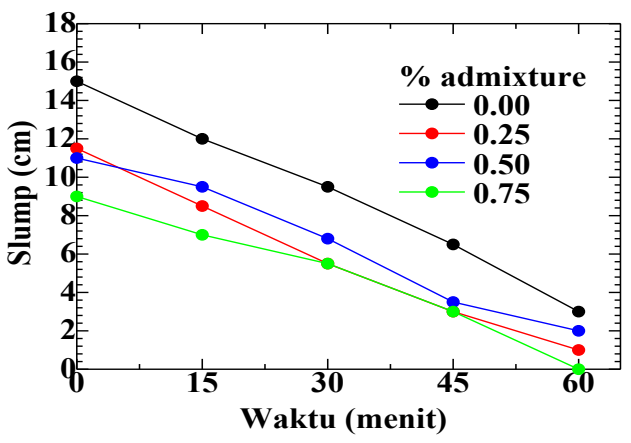

Gambar 4 Hubungan nilai slump dengan waktu pada campuran air dingin FAS 0,45

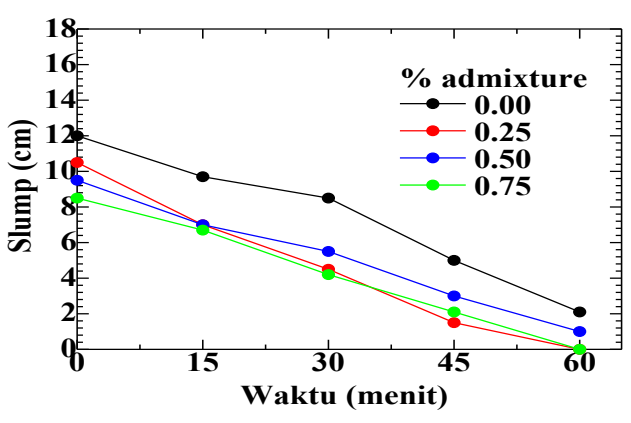

Gambar 6 Hubungan nilai slump dengan waktu pada campuran air dingin FAS 0,40

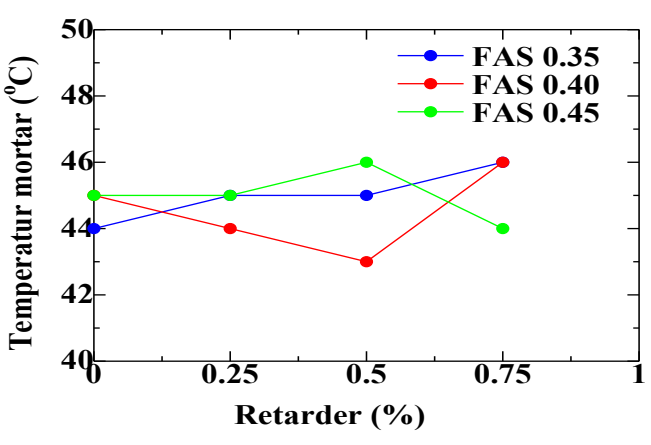

Gambar 3 Hubungan temperatur mortar dengan persentase retarder campuran air panas

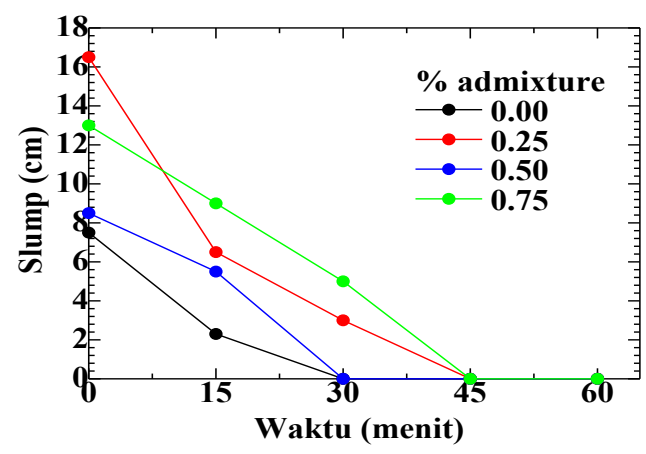

Gambar 5 Hubungan nilai slump dengan waktu pada campuran air panas FAS 0,45

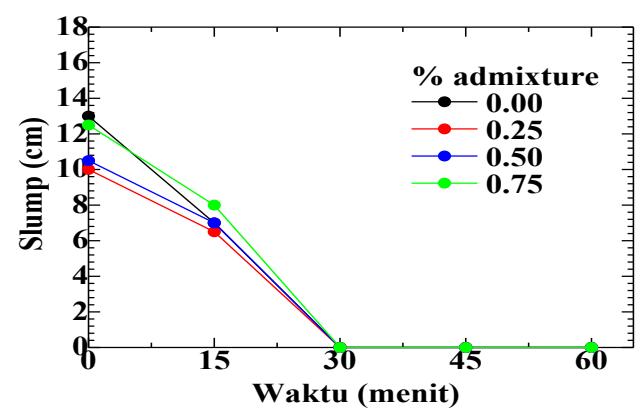

Gambar 7 Hubungan nilai slump dengan waktu pada campuran air panas FAS 0,40

Pengaruh Penggunaan Air Suhu Ekstrim Sebagai Bahan Pembentuk Beton Yang Ditambahkan Admixtures Terhadap Kuat Tekan Beton - Teuku Budi Aulia, Zahra Amalia 


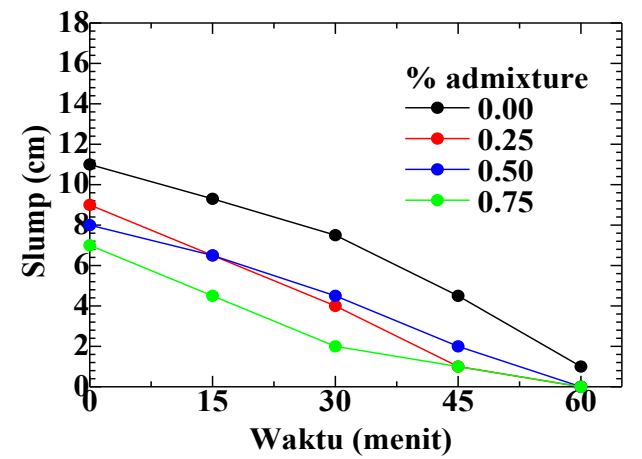

Gambar 8 Hubungan nilai slump dengan waktu pada campuran air dingin FAS 0,35

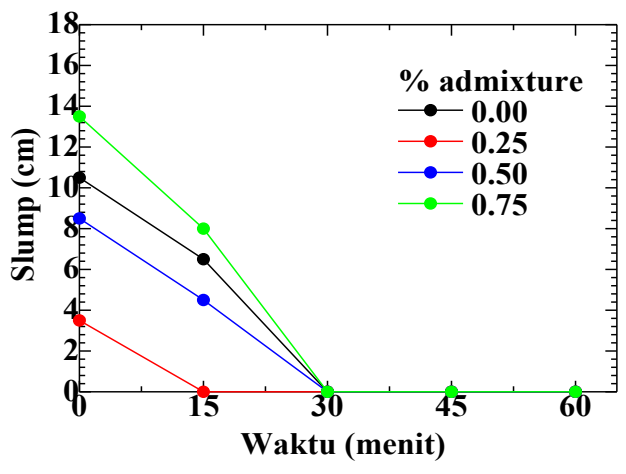

Gambar 9 Hubungan nilai slump dengan waktu pada campuran air panas FAS 0,35

Penggunaan air campuran beton bertemperatur ekstrim mempengaruhi secara signifikan waktu pengikatan semen dan workabilitasnya. (Bella, Bella dan Asroun, 2017) menyebutkan bahwa hilangnya workabilitas beton dapat terjadi karena adanya aksi ganda yaitu penguapan air dan temperatur tinggi hidrasi. Melalui pemeriksaan nilai slump, workabilitas beton yang menggunakan accelerator pada campuran air dingin dapat menurun. Berdasarkan (Hewlett, 2003), kandungan kalsium klorida $\left(\mathrm{CaCl}_{2}\right)$ pada bahan dasar accelerator sangat mudah bereaksi pada suhu rendah. Reaksi kimia antara $\mathrm{C}_{3} \mathrm{~A}$ dan $\mathrm{CaCl}_{2}$ membentuk kalsium hidroalumina, bahan yang memberikan efek yang sangat kecil selama waktu hidrasi awal pasta semen sehingga reaksi pengerasan dapat berlangsung lebih cepat.

Sebaliknya, (Hewlett, 2003) menyebutkan bahwa retarder berbahan dasar posfat atau hidroksilat polimer tertentu sebagian besar mengandung garam kompleks. Trisosium orthophosphate $\left(\mathrm{Na}_{4} \mathrm{P}_{2} \mathrm{O}_{7}\right)$ adalah zat yang paling sering digunakan. Bahan ini dapat menghambat hidrasi sehingga memperlambat waktu pengikatan semen. Pada beton dengan campuran air panas menggunakan retarder dapat meningkatkan workability. Hal ini ditunjukkan dengan lamanya waktu pengikatan beton.

\subsection{Pengaruh Temperatur Air Campuran Beton Terhadap Kuat Tekan Beton}

Hasil pengujian kuat tekan beton dengan menggunakan air campuran beton dingin dan air campuran beton panas dapat dilihat pada Gambar 10 dan Gambar 11. Garis putus-putus biru, merah dan hijau menunjukkan kuat tekan beton normal tanpa admixture untuk FAS 0,35; 0,40 dan 0,45 secara berurutan. Kuat tekan beton rata-rata yang tertinggi pada campuran air dingin yang ditambah accelerator terjadi pada FAS 0,35 dan $0,25 \%$ accelerator yaitu $476,475 \mathrm{~kg} / \mathrm{cm}^{2}$; sedangkan besarnya kuat tekan beton rata-rata yang terendah terjadi pada FAS 0,45 dan $0 \%$ accelerator yaitu $263,702 \mathrm{~kg} / \mathrm{cm}^{2}$. Besarnya kuat tekan beton ratarata yang tertinggi untuk campuran air panas yang ditambah retarder terjadi pada FAS 0,35 dengan $0,25 \%$ retarder yaitu $525,141 \mathrm{~kg} / \mathrm{cm}^{2}$; sedangkan besarnya kuat tekan beton rata-rata yang terendah terjadi pada FAS 0,45 dengan $0,75 \%$ retarder yaitu $314,632 \mathrm{~kg} / \mathrm{cm}^{2}$. Pada beton normal besarnya kuat tekan beton rata-rata yang tertinggi terjadi pada FAS 0,35 yaitu $475,909 \mathrm{~kg} / \mathrm{cm}^{2}$, sedangkan besarnya kuat tekan beton rata-rata yang terendah terjadi pada FAS 0,45 yaitu $342,360 \mathrm{~kg} / \mathrm{cm}^{2}$. 


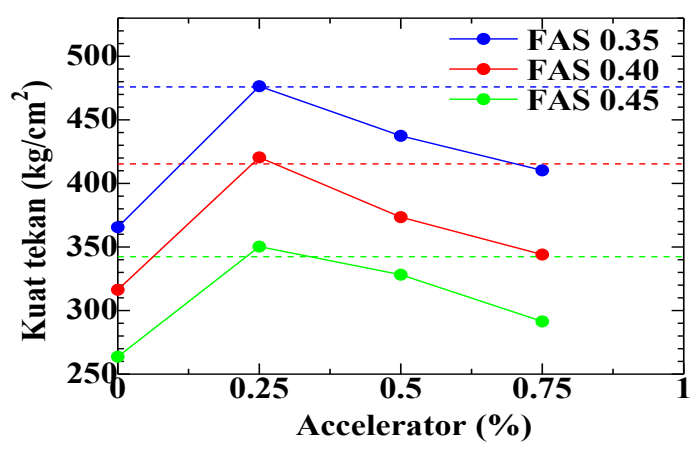

Gambar 10 Hubungan kuat tekan beton dengan persentase admixture pada campuran air dingin

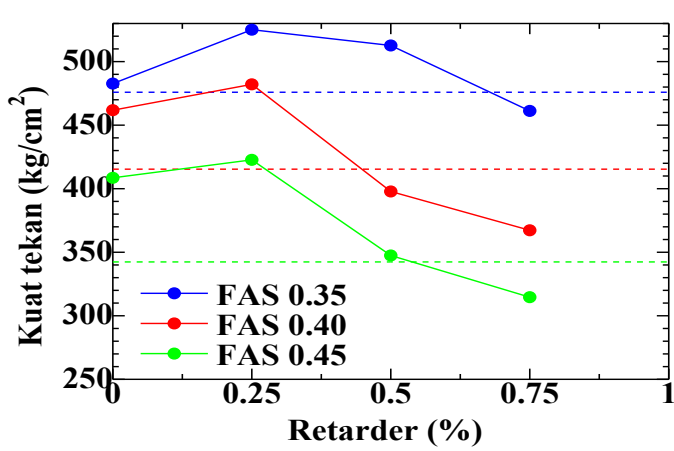

Gambar 11 Hubungan kuat tekan beton dengan persentase admixture pada campuran air panas

Hubungan tegangan dan regangan beton air campuran menggunakan air dingin dan air panas diberikan pada Gambar 12 dan Gambar 13 secara beurutan dengan variasi persentase admixtures untuk FAS 0,35. Grafik menunjukkan bahwa penggunaan air campuran beton bertemperatur ekstrim dapat menurunkan kuat tekan beton. Namun dengan tambahan admixtures sebesar 0,25\% dari berat semen, kuat tekan beton dapat meningkat jika dibandingkan dengan beton menggunakan air campuran dengan temperatur normal.

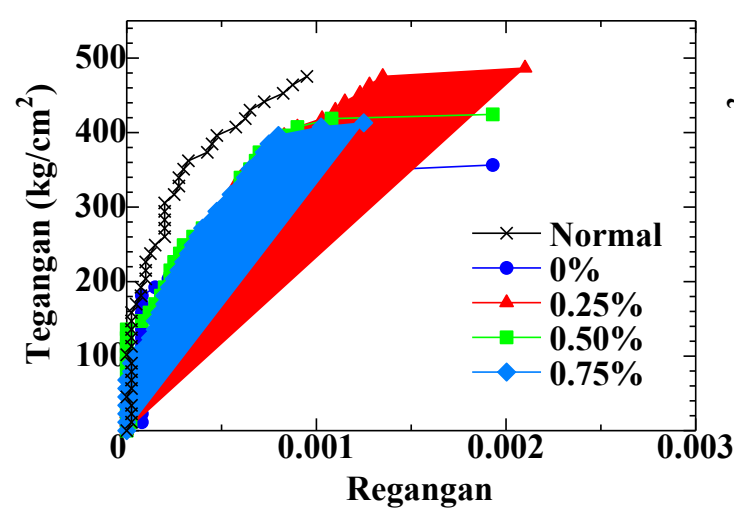

Gambar 12 Hubungan tegangan dengan regangan pada campuran air dingin

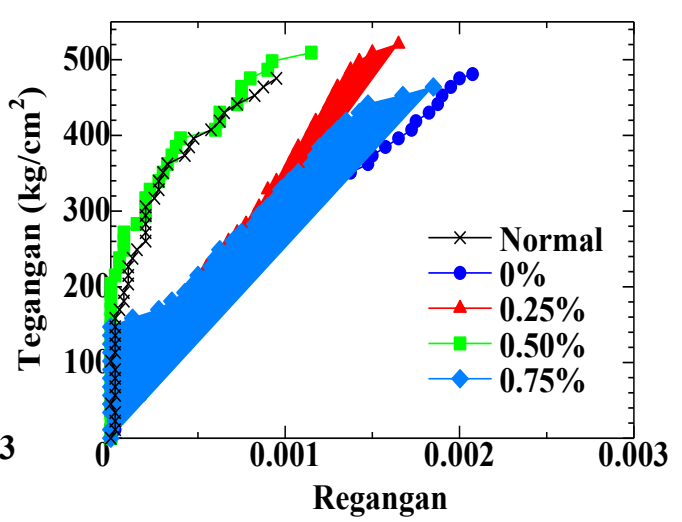

Gambar 13 Hubungan tegangan dengan regangan pada campuran air panas

Hubungan tegangan dan regangan beton air campuran menggunakan air dingin dan air panas pada FAS yang berbeda dapat dilihat pada Gambar 14 dan Gambar 15 secara berurutan dengan persentase admixtures 0,25\%. Ketiga grafik memiliki kecenderungan yang relatif sama untuk tiap beton dengan campuran air dingin dan air panas. Beton dengan air campuran bertemperatur dingin memiliki grafik yang lebih landai dengan regangan yang lebih besar, hal ini menunjukkan sifat beton yang lebih daktail.

Grafik pada Gambar 10 dan Gambar 11 menunjukkan bahwa temperatur air campuran beton dapat mempengaruhi kuat tekan beton. Tanpa adanya tambahan admixtures, kuat tekan beton mengalami penurunan jika menggunakan air campuran beton bertemperatur rendah, namun meningkat pada air campuran beton bertemperatur tinggi. Salah satu penyebabnya adalah karena perbedaan laju

Pengaruh Penggunaan Air Suhu Ekstrim Sebagai Bahan Pembentuk Beton Yang Ditambahkan Admixtures Terhadap Kuat Tekan Beton - Teuku Budi Aulia, Zahra Amalia 
hidrasi pada beton. Proses hidrasi semen sangat bergantung pada temperatur air dan lingkungan. Temperatur yang meningkat dapat menyebabkan proses pengerasan beton yang cepat jika dibandingkan dengan campuran beton menggunakan air bertemperatur normal. Hal ini disebutkan dalam penelitian yang dilakukan oleh (Renjuraj dkk., 2016; Bella, Bella dan Asroun, 2017) bahwa kekuatan yang lebih tinggi dapat terjadi pada beton dengan air campuran bertemperatur tinggi pada umur awalnya dan mengalami penurunan seiring dengan bertambahnya umur.

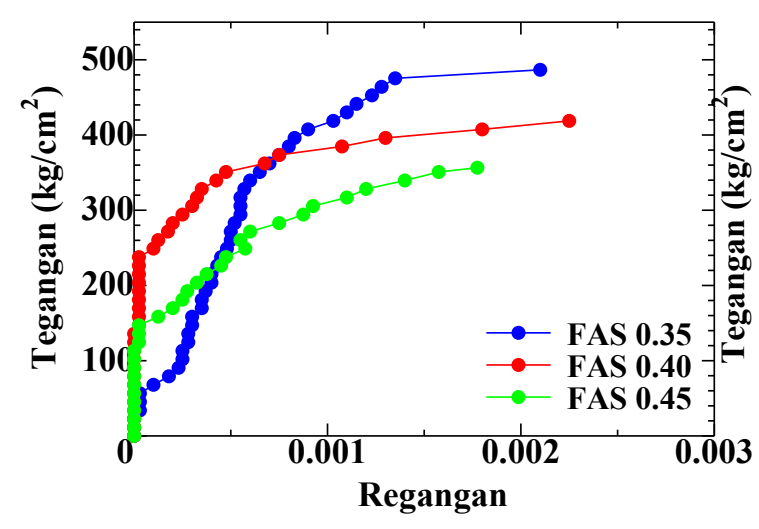

Gambar 14 Hubungan tegangan dengan regangan pada campuran air dingin $0,25 \%$ accelerator

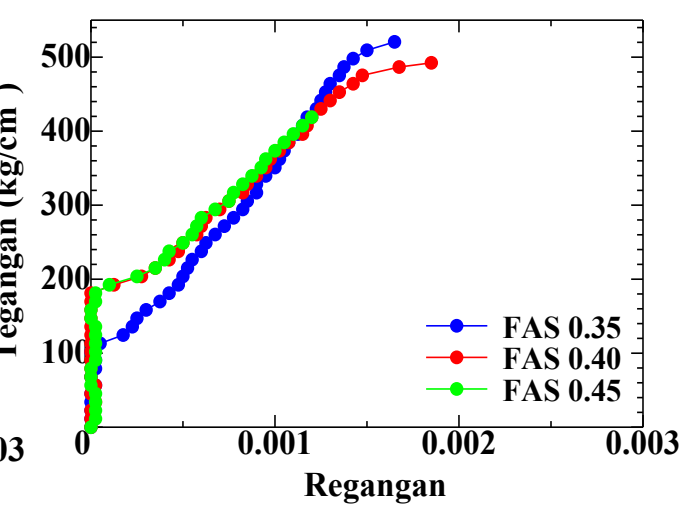

Gambar 15 Hubungan tegangan dengan regangan pada campuran air panas $0,25 \%$ retarder

\subsection{Pengaruh Variasi Persentase Admixtures dan FAS Pada Beton dengan Campuran Air Temperatur Ekstrim Terhadap Kuat Tekannya}

Berdasarkan grafik pada Gambar 10 dan Gambar 11 menunjukkan bahwa penggunaan admixtures pada beton yang menggunakan air campuran bertemperatur ekstrim memiliki nilai optimum pada persentase $0,25 \%$. Nilai ini ditunjukkan pada kedua perlakuan beton (campuran air dingin dan air panas) yang ditambahkan accelerator dan retarder secara berurutan. Penurunan kuat tekan beton terjadi seiring dengan bertambahnya persentase admixtures. Tabel 4 dan Tabel 5 memberikan informasi hasil analisis varian untuk variasi persentase admixtures dan FAS pada campuran air bertemperatur ekstrim. Hasil perhitungan analisis varian menunjukkan bahwa $\mathrm{F}_{0}$ hitung lebih besar dari $\mathrm{F}_{0}$ tabel, hal ini membuktikan bahwa FAS dan penggunaan admixtures pada campuran air bertemperatur ekstrim sebagai bahan pembentuk beton memiliki pengaruh yang signifikan terhadap kuat tekannya.

Hubungan antara persentase admixtures dan FAS terhadap kuat tekan beton yang menggunakan air bertemperatur ekstrim dilakukan dengan analisis regresi. Nilai koefisien determinan tertinggi menggunakan regresi polinomial berderajat dua (2) diperoleh sebesar 0,910 untuk beton yang menggunakan air dingin dan 0,925 untuk beton yang menggunakan air panas.

Pengaruh Penggunaan Air Suhu Ekstrim Sebagai Bahan Pembentuk Beton Yang Ditambahkan Admixtures Terhadap Kuat Tekan Beton - Teuku Budi Aulia, Zahra Amalia 
Tabel 4 analisis varian pengaruh penggunaan air dingin terhadap kuat tekan beton yang ditambahkan accelerator

\begin{tabular}{lccccc}
\hline Sumber variasi & $\begin{array}{c}\text { Jumlah } \\
\text { kuadrat }\end{array}$ & $\begin{array}{c}\text { Derajat } \\
\text { kebebasan }\end{array}$ & $\begin{array}{c}\text { Rata-rata } \\
\text { kuadrat }\end{array}$ & $\mathbf{F}_{\mathbf{0}}$ Hitung & $\mathbf{F}_{\mathbf{0}}$ Tabel \\
\hline Admixtures & 83101.583 & 3 & 27700.528 & 391.713 & 2.808 \\
FAS & 130063.643 & 2 & 65031.822 & 919.615 & 3.198 \\
Interaksi & 1431.406 & 6 & 238.568 & 3.374 & 2.344 \\
Error & 3394.385 & 48 & 70.716 & & \\
Total & 217991.017 & 59 & & & \\
\hline
\end{tabular}

Tabel 5 Analisis varian pengaruh penggunaan air panas terhadap kuat tekan beton

\begin{tabular}{lccccc}
\multicolumn{6}{c}{ yang ditambahkan retarder } \\
\hline Admixtures & $\begin{array}{c}\text { Jumlah } \\
\text { kuadrat }\end{array}$ & $\begin{array}{c}\text { Derajat } \\
\text { kebebasan }\end{array}$ & $\begin{array}{c}\text { Rata-rata } \\
\text { kuadrat }\end{array}$ & F $_{\mathbf{0}}$ Hitung & F $_{\mathbf{0}}$ Tabel \\
FAS & 76725.237 & 3 & 25575.079 & 519.453 & 2.808 \\
Interaksi & 149739.067 & 2 & 74869.533 & 1520.669 & 3.198 \\
Error & 18169.832 & 6 & 3028.305 & 61.508 & 2.344 \\
Total & 2363.260 & 48 & 49.235 & & \\
\hline
\end{tabular}

\section{Kesimpulan dan Saran}

\subsection{Kesimpulan}

Berdasarkan hasil penelitian dapat disimpulkan bahwa air temperatur ekstrim yang ditambahkan accelerator dan retarder sebagai bahan pembentuk beton berpengaruh secara signifikan terhadap kuat tekan beton apabila dibandingkan dengan kuat tekan beton menggunakan air temperatur normal tanpa penambahan accelerator dan retarder. Nilai optimum dalam penggunaan accelerator dan retarder yang dapat meningkatkan kuat tekan beton diperoleh pada persentase $0,25 \%$ dari berat semen untuk masing-masing FAS 0,$35 ; 0,40$; dan 0,45 . Workabilitas beton yang menggunakan air bertemperatur ekstrim dipengaruhi oleh penambahan accelerator dan retarder.

\subsection{Saran}

Berdasarkan penelitian yang telah dilakukan, disarankan untuk melakukan penelitian lanjutan dengan menambah variasi umur beton agar diketahui pengaruh penggunaan air bertemperatur ekstrim seiring dengan bertambahnya umur beton. Selain itu disarankan untuk menambah jumlah variasi temperatur air campuran agar dapat menghasilkan kesimpulan yang lebih detail dan akurat.

\section{Daftar Kepustakaan}

ACI Committee 211, 2009. 211.1-91 Standard Practice for Selecting Proportions for Normal Heavyweight, and Mass Concrete, Concrete.

American Society for Testing and Materials, 2014. 'ASTM C136 / C136M - 14 Standard Test Method for Sieve Analysis of Fine and Coarse Aggregates', ASTM International. doi: 10.1520/C0136.

Pengaruh Penggunaan Air Suhu Ekstrim Sebagai Bahan Pembentuk Beton Yang Ditambahkan Admixtures Terhadap Kuat Tekan Beton - Teuku Budi Aulia, Zahra Amalia 
Amri, S., 2005. Teknologi Beton A - Z. Jakarta: Yayasan John Hi-Tech IDETAMA.

Assal, M. dan Abou-Zeid, M. N., 2019. 'The effect of mixing water temperature on concrete properties in hot weather conditions', in 7th International Materials Specialty Conference 2018, Held as Part of the Canadian Society for Civil Engineering Annual Conference 2018.

ASTM, 1997. 'ASTM C 128: Standard Test Method for Specific Gravity and Absorption of Fine Aggregate', Annual Book of ASTM Standards.

ASTM, 2008. 'ASTM C39 Standard Test Method for Compressive Strength of Cylindrical Concrete Specimens 1', ASTM International.

ASTM C127, 2004. Standard Test Method for Density, Relative Density (Specific Gravity), and Absorption of Coarse Aggregate, Annual Book of ASTM Standards.

ASTM International, 2004. 'ASTM C40. Organic Impurities in Fine Aggregates for Concrete', United States : American Standard Testing and Material.

Bella, N., Bella, I. A. dan Asroun, A., 2017. 'A review of hot climate concreting, and the appropriate procedures for ordinary jobsites in developing countries', MATEC Web of Conferences, 120, pp. 1-10. doi: 10.1051/matecconf/201712002024

Gere, J. M. dan Timoshenko, S., 1997. Mechanic of Material. PWS Publishing Company.

Hewlett, P. C., (2003) Lea's Chemistry of Cement and Concrete, Lea's Chemistry of Cement and Concrete. doi: 10.1016/B978-0-7506-6256-7.X5007-3.

Madi, M. dkk., 2017 'The impact of mixing water temperature on portland cement concrete quality', in 6th International Conference on Engineering Mechanics and Materials 2017.

Mulyono, T., 2003. Teknologi Beton, Penerbit Andi. doi: 10.1038/cddis.2011.1.

Naganathan, S. dan Mustapha, K. N., 2015. 'Effect of water temperature on concrete properties', Jordan Journal of Civil Engineering. doi: 10.14525/jjce.9.3.3072.

PT. Sika Indonesia, 2007. 'Brosur Sika'. Jakarta.

Renjuraj, R. dkk. 2016 'Effect on Workability and Strengthof Concrete due to Variation in Mixing Water Temperature', 7(4), pp. 185-188.

SNI 1974, 2011. 'Cara Uji Kuat Tekan Beton dengan Benda Uji Silinder', Badan Standardisasi Nasional Indonesia.

SNI, 2847:2013, 2013. 'Persyaratan Beton Struktural untuk Bangunan Gedung', Bandung: Badan Standardisasi Indonesia.

Copyright (c) Teuku Budi Aulia

Pengaruh Penggunaan Air Suhu Ekstrim Sebagai Bahan Pembentuk Beton Yang Ditambahkan Admixtures Terhadap Kuat Tekan Beton - Teuku Budi Aulia, Zahra Amalia 